the desirable effect of directing the courts' attention to the significant elements in all these cases. Courts which de-emphasize the importance of these elements and concentrate instead on ambiguous concepts like "corporate transaction," as in the Seltzer case, and "corporate opportunity," as in the Feldmann case, increase the danger that subsequent courts will misconstrue the extent of a holding and either impose or refuse liability without regard for the former two elements.

Furthermore, the use of such concepts as "corporate transaction" and "corporate opportunity" will distract the courts from the proper measure of damages, which should not be the profit the controlling shareholder receives, but rather the extent of damage to the corporation. When emphasis is placed on the existence of the injury and the violation of a standard of care which led to it, the court will be induced to think of the tort measure of damages-compensation for the injury. It is highly appropriate that a controlling shareholder be required to rectify an injury he knowingly caused, and not merely be required to divest himself of profits he hoped to obtain from his wrong.

under not to assist another to commit a tort rather than the obligation of a fiduciary." Judge Swan did not find for the plaintiff because he believed the trial judge was correct in finding that Newport had not been injured.

\title{
CORROBORATION OF ADMISSIONS
}

A difficult burden is imposed on the prosecution when acts which are normally noncriminal constitute the external evidence of the crime, when a specific intent must be proved, and when the relevant facts are largely within the control of the defendant. In these situations the prosecution may be forced to rely heavily on extrajudicial statements ${ }^{1}$ of the accused, and courts may be tempted to relax rules of corroboration ${ }^{2}$ relating to admissions and confessions. $^{3}$

\footnotetext{
1 "Statements" is used herein to include admissions and confessions. Judicial statements are those made in open court. As to the boundaries of what constitutes a judicial statement, consult Proof of the Corpus Delicti Aliunde the Defendant's Confession, 103 U. of Pa. L. Rev. 638, 668 (1955).

${ }^{2}$ Corroboration as a requirement for sufficiency of proof applies only in criminal cases. A confession has no counterpart in civil cases. Extrajudicial admissions in criminal cases are treated significantly differently from extrajudicial admissions in civil cases. Both constitute sweeping exceptions to the hearsay rule, resting on the adversary theory of litigation. If the declarant is a party, he can "hardly object that he had no opportunity to cross examine himself or that he is unworthy of credence save when speaking under the sanction of oath." Morgan, Handbook of Evidence 231 (1954).

${ }^{3}$ A confession is an express acknowledgment of guilt, or an acknowledgment of all facts pertaining to a crime from which no other hypothesis can be supported except that of guilt. Admissions are acknowledgments of one or more facts consistent with a hypothesis of guilt, but which fall short of supplying all of the essential elements necessary to constitute the offense charged. 3 Wigmore, Evidence $\$ 821$, at 243 (3d ed., 1940). For a case discussing the distinction between an admission and a confession see People v. Fowler, 178 Cal. 657, 174 Pac. 892 (1918). See note 19 infra.
} 
The crime of tax evasion illustrates this problem. It consists of payment of less tax than the amount known by the taxpayer to be legally due, with an intent to defraud the government. ${ }^{4}$ In the typical prosecution for tax evasion the government establishes that the accused knowingly reported less income than he received in a given year or years. Another method of proof is available, the so-called net-worth method. ${ }^{5}$ If the prosecution can establish (1) the amount of property owned by the defendant at the starting point, (2) the amount of property owned by the defendant at the close of the prosecution period (and/or the total expenditures by the defendant during the period), and (3) the amount of nontaxable receipts (gifts, bequests, loans, etc.) received by the defendant during the period, a conviction for tax evasion may be upheld. If the increase in net worth during the period exceeds the total of reported income and nontaxable receipts, the government has established its case. To require that the prosecution negative every innocent explanation of an increase in net worth in excess of reported income (such as gifts or bequests) is indeed to lay upon it a difficult burden. ${ }^{6}$ The prosecution may

\footnotetext{
"Portions of 26 U.S.C.A. $\$ 145$ (a) and (b) have been altered by $\$ 7201$ of the Internal Revenue Code of 1954 to read as follows: "Any person who willfully attempts in any manner to evade or defeat any tax imposed by this title or the payment thereof shall, in addition to other penalties provided by law, be guilty of a felony and, upon conviction thereof, shall be fined not more than $\$ 10,000$, or imprisoned not more than 5 years, or both, together with the costs of prosecution."
}

${ }^{5}$ The Supreme Court described the net-worth method as follows in Holland v. United States, 348 U.S. 121, 125 (1954): "In a typical net worth prosecution the Government, having concluded that the taxpayer's records are inadequate as a basis for determining income tax liability, attempts to establish an 'opening net worth' or total net value of the taxpayer's assets at the beginning of a given year. It then proves increases in the taxpayer's net worth for each succeeding year during the period under examination and calculates the difference between the adjusted net values of the taxpayer's assets at the beginning and end of each of the years involved. The taxpayer's nondeductible expenditures, including living expenses, are added to these increases, and if the resulting figure for any year is substantially greater than the taxable income reported by the taxpayer for that year, the Government claims the excess represents unreported taxable income. In addition, it asks the jury to infer willfulness from this understatement, when taken in connection with direct evidence of 'conduct, the likely effect of which would be to mislead or to conceal.'"

'In Holland v. United States, ibid., at 137-38, the Court said: "But petitioners claim the Government failed to adduce adequate proof because it did not negative all the possible nontaxable sources of the alleged net worth increases-gifts, loans, inheritances, etc. We cannot agree. The Government's proof, in our view, carried with it the negations the petitioners urge. Increases in net worth, standing alone, cannot be assumed to be attributable to currently taxable income. But proof of a likely source, from which the jury could reasonably find that net worth increases sprang, is sufficient." As to the sufficiency of the government's investigative procedure, the Court said, "When the Government rests its case solely on the approximations and circumstantial inferences of a net worth computation, the cogency of its proof depends upon its effective negation of reasonable explanations by the taxpayer inconsistent with guilt. Such refutation might fail when the Government does not track down relevant leads furnished by the taxpayer-leads reasonably susceptible of being checked, which, if true, would establish the taxpayer's innocence." Ibid., at $135-36$. 
be forced to rely on the extrajudicial statements of the accused to prove facts peculiarly within his knowledge and control. If, however, it must "corroborate" the confession or admission, the burden may render the net-worth method unworkable. In several recent cases, the Supreme Court has sustained the applicability of the requirement of corroboration to extrajudicial admissions. ${ }^{7}$

We choose to apply the [corroboration] rule, with its broader guarantee, to crimes in which there is no tangible corpus delicti, where the corroborative evidence must implicate the accused, in order to show a crime has been committed. ${ }^{8}$

The usual rule in the United States is that no person can be convicted of a crime solely on the basis of an extrajudicial confession; ${ }^{9}$ at least some independent evidence tending to show that a crime has been committed is necessary. ${ }^{10}$ Such evidence need not, however, link the accused with the crime; ${ }^{11}$

7 Opper v. United States, 348 U.S. 84 (1954); Smith v. United States, 348 U.S. 147 (1954); United States v. Calderon, 348 U.S. 160 (1954). The Smith and Calderon cases were concerned with the sufficiency of an extrajudicial admission as proof of facts it embraced. In the Opper case, the additional question of competency was also raised. The requirement of corroboration may come into play at two different stages of a criminal prosecution; first as a prerequisite to the admission of the statements into evidence, and later as a requirement to be met if the prosecution's proof is to be sufficient to sustain a conviction. For cases holding that corroboration is required for admissibility see, e.g., Smith v. State, 135 Fla. 835, 186 So. 203 (1939); Commonwealth v. Turza, $340 \mathrm{~Pa}$. 128, 16 A. 2d 401 (1940); Tabor v. U.S., 152 F. 2d 254 (C.A. 4th, 1945); United States v. DiOrio, 150 F. 2 d 938 (C.A. 3d, 1945). Whether the requirement of corroboration has been met may determine whether statements are to be admitted for the jury's consideration; this is a question for the judge. Corroborative evidence, as it affects credibility, may determine what weight the jury will place on the statements of the accused. In many cases the same independent evidence will serve to make the extrajudicial statements competent, and will also satisfy the requirement as to sufficiency of proof. It is difficult to offer a wholly satisfactory rationale as to why a requirement of corroboration exists in order to make extrajudicial statements competent as evidence when their voluntary nature has been established and when corroboration will be required if the evidence is to be suffcient to convict. Perhaps it is desirable to exclude uncorroborated statements at the earliest possible time.

${ }^{8}$ Smith v. United States, 348 U.S. 147, 154 (1954).

' 7 Wigmore, Evidence $\$ 2071$ (3d ed., 1940). Consult Corroboration of Confession, 127 A.L.R. 1130 (1940). Massachusetts appears to be the sole exception to this rule. Commonwealth v. Kimball, 321 Mass. 290, 73 N.E. 2d 468 (1947), holds that no corroboration of a confession is necessary. In nine states corroboration of a confession is required by statute. Consult U. of Pa. L. Rev., op. cit. supra note 1 , at 641 .

${ }^{10}$ Some courts have phrased the rule of a requirement of corroboration in terms of a requirement of independent evidence establishing the corpus delicti, a requirement which may seem to impose a greater burden of proof on the prosecution. It seems doubtful, however, whether the form of the rule is of real significance in the application of the criminal law. See U. of Pa. L. Rev., op. cit. supra note 1. "Corpus delicti," as used herein, includes two elements: first, that events have occurred which have resulted in a loss or injury, and second, that these detrimental effects were produced by a criminal act. 7 Wigmore, Evidence $\$ 2072$ (3d ed., 1940). A third element, the identity of the perpetrator of the crime, must be established, in addition to the corpus delicti, if the prosecution is to sustain its burden of proof.

"Prof. Wigmore supports this rule, saying, "A third view, indeed, too absurd to be argued with, has occasionally been advanced, at least by counsel, namely, that the 'corpus 
the accused's extrajudicial statements alone are sufficient to establish him as the perpetrator of the crime. A judicial confession, on the other hand, is equivalent to a plea of guilty and requires no corroboration..$^{12}$

Courts have adopted widely varying verbal formulae indicating the amount of independent evidence needed to "corroborate" the extrajudicial statements of the defendant. ${ }^{13}$ At one extreme, independent evidence showing that an

delicti' includes the third element also, i.e. the accused's identity or agency as the criminal. By this view, the term 'corpus delicti' would be synonymous with the whole of the charge, and the rule would require that the whole be evidenced in all three elements independently of the confession, which would be absurd." 7 Wigmore, Evidence $\$ 2072$ (3d ed., 1940). See cases cited by Wigmore in this section, note 4 , supporting this minority view requiring independent evidence to establish the identity of the criminal.

127 Wigmore, Evidence $\$ 2071$, at 400 (3d ed., 1940); People v. Manske, 399 Ill. 176, 77 N.E. 2d 164 (1948); Skaggs v. State, 88 Ark. 62, 113 S.W. 346 (1908). It can be argued that there is no sufficient basis for a distinction between extrajudicial statements of an accused, shown to be voluntary, and statements made judicially, which require no corroboration. Extrajudicial statements of an accused are hearsay, and for this reason are said to be untrustworthy. The requirement of corroboration is applied as a remedy purporting to cure untrustworthiness.

When an accused makes a judicial statement, he is more likely to be fully aware of the consequences of his statements. He has had opportunity for advice of counsel, and he has had occasion to observe the solemn nature of court proceedings. In the case of oral extrajudicial statements there is danger that they may be inaccurately reported. There is danger that error may occur in determining the voluntariness of the statements. But the danger that the defendant may make false admissions or confessions because of a desire to protect a guilty person, or because of psychological unbalance, is certainly not eliminated when the statements are made judicially. It might be argued that any connection between trustworthiness and evidence obtained by judicial statements of the accused is illusory, and that there is no sound basis for a presumption that judicial statements are more trustworthy than voluntary extrajudicial statements. On the other hand it may be argued that corroboration of extrajudicial statements discourages improper coercive methods by police officers in attempting to obtain statements from the accused. If police officers know that evidence in addition to the statements of the accused must be obtained, the inducement to use coercive methods is reduced. But this may be answered by pointing to mechanisms designed to throw out involuntary confessions. If these are effective, it may be argued that there is nothing to distinguish extrajudicial statements voluntarily made from judicial statements, and that therefore a requirement of corroboration should be abolished. But even if it can be shown that involuntary confessions cannot be effectively eliminated, any device which tends to lessen improper police methods is still desirable. Even after their voluntary nature has been determined, a feeling of unreliability as to the accused's extrajudicial statements may persist, which may not be the case with judicial statements.

${ }^{13}$ Burrows v. State, 38 Ariz. 99, 297 Pac. 1029 (1931) (sufficient if independent evidence is clear and convincing); Hill v. State, 207 Ala. 444, 93 So. 460 (1922) (independent evidence based on inconclusive facts and circumstances tending prima facie to show the corpus delicti held sufficient); Gallegos v. State, 152 Neb. 831, 43 N.W. $2 \mathrm{~d} 1$ (1950) (slight independent evidence held sufficient); Pope v. State, 158 Miss. 794, 131 So. 264 (1930) (corpus delicti established by a preponderance of independent evidence held sufficient); State v. Mabry, 324 Mo. 239, 22 S.W. 2d 639 (1929) (independent evidence not completely establishing the corpus delicti held sufficient). Consult Extra-Judicial ConfessionsSufficiency of Corroboration, $33 \mathrm{Neb}$. L. Rev. 495 (1954). The use of adjectives with different quantitative connotations ("some," "slight," "substantial") is not of great significance so far as the practical application of the tests is concerned. Pennsylvania is the sole jurisdiction requiring independent evidence to establish the corpus delicti beyond a rea- 
injury has occurred which might have been caused by a criminal act might be said to be sufficient corroboration. At the other, independent evidence sufficient to establish every element of the crime, including the identity of the criminal, might be required. Such a rule would make the accused's statements merely corroborative of the independent evidence. The extrajudicial confession or admission and the independent evidence together must convince the jury beyond a reasonable doubt that a crime has been committed and that the defendant is the perpetrator.

Federal courts have advanced three different formulae to describe the amount of corroborative evidence needed to sustain a conviction. The most stringent requirement is that corroborative evidence must independently tend to establish the whole of the corpus delicti. ${ }^{14}$ Less stringent is the requirement set forth in some cases that corroborative evidence is sufficient if it touches any element of the corpus delicti and tends to fortify the truth of the confession. ${ }^{15}$ Language in other cases appears to require only that corroborative evidence tend to establish the trustworthiness of, or to fortify the truth of, the confession. ${ }^{16}$ The Supreme Court has now applied these rules to admissions. ${ }^{17}$

The problem of corroboration of admissions may be posed in this way: if the prosecution must prove facts $A, B$, and $C$, and the accused admits $A$, what independent evidence will satisfactorily corroborate $A$ ? One alternative is to consider independent proof of $\mathrm{B}$ and $\mathrm{C}$ as corroborating $\mathrm{A}$. While in many instances proof of $B$ and $C$ will increase confidence in the reliability of the accused's admission of $\mathrm{A}$, there is no necessary logical connection between $A$ and $B$, or $A$ and $C$. In the case of a confession (the accused acknowledging $A$ and $B$ and $C$ ), if there is independent corroborative evidence of $A$, the corroboration is sufficient unless the test that independent evidence is needed to establish the whole of the corpus delicti were to be applied. B and C, even

sonable doubt. See U. of Pa. L. Rev., op. cit. supra note 1 , at 659 and 675 , where it is concluded that "the fact that Pennsylvania imposes a stringent requirement has been of little consequence to date."

${ }^{14}$ Forte v. United States, 94 F. 2d 236 (App. D.C., 1937); Ercoli v. United States, 131 F. 2d 354 (App. D.C., 1940) ; Pine v. United States, 123 F. 2 d 825 (C.A. 8th, 1942) ; Ryan v. United States, 99 F. 2d 864 (C.A. 8th, 1938) ; United States v. Fenwick, 177 F. 2d 488 (C.A. 7th, 1949).

${ }^{15}$ Daesche v. United States, 250 Fed. 566 (C.A. 2d, 1918); Jordan v. United States, 60 F. 2d 4 (C.A. 4th, 1932); United States v. Kertess, 139 F. 2d 923 (C.A. 2d, 1944); Forlini v. United States, 12 F. 2d 631 (C.A. 2d, 1926).

${ }^{16}$ Pearlman v. United States, 10 F. 2d 460 (C.A. 9th, 1926); Wynkoop v. United States, 22 F. 2d 799 (C.A. 9th, 1927); Bolland v. United States, 238 Fed. 529 (C.A. 4th, 1916).

${ }^{17}$ Smith v. United States, 348 U.S. 147 (1954). In Opper v. United States, 348 U.S. 84, 91 (1954), the Court said: "The need for corroboration extends beyond complete and conscious admission of guilt-a strict confession. Facts admitted that are immaterial as to guilt or innocence need no discussion. But statements of the accused out of court that show essential elements of the crime ... necessary to supplement an otherwise inadequate basis for conviction, stand differently. Such admissions have the same possibilities for error as confessions. They, too, must be corroborated." 
though untouched by independent evidence, are corroborated by evidence concerning $\mathrm{A}$. By analogy, an admission of $\mathrm{A}$ alone should be held corroborated by independent proof of $\mathrm{B}$ or $\mathrm{C}$; if it were not, a stricter rule would apply to an admission than to a confession. A second alternative is to require some evidence of $\mathrm{A}$ aside from the admission. A final possibility is to require external evidence. which, in the general language of some courts, tends to fortify the truth of the facts contained in the admission.

In Calderon v. United States, ${ }^{18}$ a tax evasion prosecution under the networth method, the defendant taxpayer had made a voluntary ${ }^{19}$ written statement that he had $\$ 500$ cash on hand at the beginning of the prosecution period. The defendant, who later testified that his cash on hand at the beginning of the period was much greater, argued that there was not sufficient independent evidence to corroborate his extrajudicial admission as to cash on hand at the starting point, and that therefore a conviction should not be sustained. ${ }^{20}$

If the defendant's financial position at the starting point cannot be proved, no conviction can result because the prosecution has failed to show that the defendant had not previously accumulated property from which expenditures and investments in excess of reported income during the prosecution period might have been made. Merely proving expenditures and investments in excess of reported income during the prosecution period, which the government had done in the Calderon case, should not be sufficient to sustain a conviction. It is

18348 U.S. 160 (1954).

${ }^{10}$ Confessions are not admissible in evidence until their voluntary character has been established through a preliminary hearing by the judge, or by both the judge and jury. Consult Duty of Court To Institute Preliminary Investigation as to Voluntary or Involuntary Character of Confession, 102 A.L.R. 605 (1936), and Meltzer, Involuntary Confessions: Allocation of Responsibilities between Judge and Jury, 21 U. of Chi. L. Rev. 317 (1954). This requirement has its roots in a feeling that extrajudicial confessions may be untrustworthy and that their receipt into evidence without establishing their voluntary character would be an inducement to police officers to use improperly coercive methods to obtain confessions. Some jurisdictions, including federal courts, place extrajudicial admissions in the same category as extrajudicial confessions as to the requirement of a preliminary determination of voluntariness. Ashcraft v. Tennessee, 327 U.S. 274 (1946); Gulotta v. United States, 113 F. 2d 683 (C.A. 8th, 1940) ; McGuire v. State, 299 Ala. 315, 194 So. 815 (1940) ; Louette v. State, 152 Fla. 492, 12 So. 2d 168 (1943). Other jurisdictions have no such requirement as to admissions. Commonwealth v. Haywood, 247 Mass. 16, 141 N.E. 571 (1923); State v. Lindsey, 26 N.M. 526, 194 Pac. 877 (1921) ; State v. Gibson, 69 N.D. 70, 284 N.W. 209 (1938); People v. Crowl, 28 Cal. App. 2d 299, 82 P. 2d 507 (1938); People v. Fowler, 178 Cal. 657, 174 Pac. 892 (1918). Thus, whether the accused's statements are characterized as an admission or a confession may be crucial. Consult Validity of the Admission-Confession Distinction for Purposes of Admissibility, $39 \mathrm{~J}$. of Crim. L. \& Criminology 743 (1949). The dichotomy drawn by the definition of an admission and the definition of a confession does not furnish a rational basis for determining whether statements made by an accused person are to be accorded a determination of voluntariness. By introducing into evidence improperly induced admissions, the policies against admitting improperly induced confessions are violated.

${ }^{20}$ The Court does not explicitly consider the question of whether the defendant might have had nontaxable receipts during the prosecution years. 
necessary for the government to establish the net worth at the starting point, an excess of expenditures and investments over reported income during the prosecution period, and the absence of nontaxable receipts. While there was some evidence that the defendant's economic circumstances were very modest prior to the prosecution period, the Court held that such evidence was too remote and inconclusive to corroborate the admission. The Court found, however, that proof of increase in the defendant's visible assets during the prosecution period, greatly exceeding reported income during the period, supported an inference of tax evasion, and sufficiently corroborated the admission.

Because the evidence of the defendant's economic circumstances prior to the prosecution period was insufficient to corroborate the defendant's admission, the Court said, "Accordingly, we must search for independent evidence which will tend to establish the crime directly, without resort to the net-worth method."21 The Court does not seem to mean that it is wholly abandoning the net-worth theory in this particular case, but that an intermediate step has been interposed: a search for evidence which will tend to establish the whole of the corpus delicti and therefore corroborate the admission. The defendant's investment policy during the prosecution period was so inconsistent with his reported income during the period that it "support[ed] an inference of tax evasion."22 This evidence is thus sufficient to corroborate the defendant's admission of his opening net worth.

The companion case of Smith v. United States ${ }^{23}$ presented a similar fact situation, except that there it was held that sufficient independent evidence of the defendant's modest economic circumstances prior to the prosecution period existed to corroborate the defendant's admission of his net worth. The evidence was in the form of income tax returns. Apparently the evidence was sufficient because it fortified the truth of the admission. The Court indicates that evidence relating to the financial history of the defendant during the prosecution period "might not, of [itself], suffice to support a conviction of tax evasion without evidence of a starting point. ..."24 It may be questioned whether evidence of expenditures in excess of reported income even tends to establish the crime of tax evasion. It establishes circumstances which are consistent with either criminal or noncriminal conduct. Thus, if the test for establishment of the corpus delicti by independent evidence merely requires that such evidence show that the occurrence might have been perpetrated by a criminal act, the test is met in both the Calderon and Smith cases. This relaxed standard of establishing the whole of the corpus delicti does not substantially increase the burden of the prosecution. It is difficult to imagine a case in which any substantial possibility of conviction existed where such a

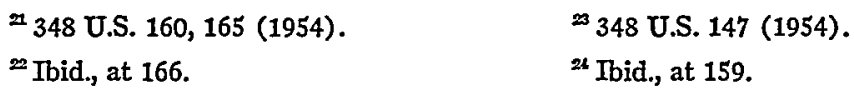


requirement could not be met. In the Smith case the Court said: "But this conduct [spending during the prosecution years] does corroborate the net worth statement by tending to show that the petitioner was understating his income during the prosecution years." 25 Thus the Court indicates that this line of corroboration is available and sufficient as an alternative, although not needed in the Smith case, as it was in the Calderon case. Lavish expenditures during the prosecution period would seem sufficient to establish the crime of tax evasion only where it was not necessary to establish the defendant's net worth at the starting point, because the government has some other evidence tending to show that income which was not reported was received during the prosecution period.

In the Calderon and Smith cases the admission did not technically touch the corpus delicti-the payment of less tax than the amount known to be owing with an intent to defraud. The facts embraced in the admission, however, when combined with evidence of expenditures during the prosecution period and evidence that no property not subject to tax was received, do prove that income was understated in the tax returns. Thus, when the networth method is used, the admission of opening net worth may be considered as a formal element of the crime. In the Smith case the Court said:

An admission which assumes this importance in the presentation of the prosecution's case should not go uncorroborated, and this is true whether we consider the statement an admission of the formal "elements" of the crime or of a fact subsidiary to the proof of these "elements." It is the practical relation of the statement to the Government's case which is crucial, not its theoretical relation to the definition of the offense. ${ }^{2 B}$

If the opening net worth and the expenditures during the prosecution period are considered to be the formal elements of the crime, and if a formal element of a crime is treated as an element of the corpus delicti, in the Calderon case none of the tests for corroboration have been met. The defendant's extrajudicial admission of his net worth must be corroborated by one of the following: ${ }^{2 \pi}$ independent evidence which tends to establish all elements of the corpus delicti (not met here because there is no independent evidence of the opening net worth); independent evidence which touches an element of the corpus delicti and which tends to fortify the truth of the admission (evidence

$$
{ }^{x} \text { Ibid. } \quad{ }^{20} \text { Ibid., at } 155 .
$$

${ }^{2}$ Using the possible tests laid down by the Supreme Court in Opper v. United States, 348 U.S. 84 (1954). In this case the Court follows the rule "that corroborative evidence need not be sufficient, independent of the statements, to establish the corpus delicti. It is necessary, therefore, to require the Government to establish the trustworthiness of the statement. Thus, the independent evidence serves a dual function. It tends to make the admission reliable, thus corroborating it while also establishing independently the other necessary elements of the offense." Ibid., at 93. Surely the Court is not suggesting that this is true in every case. Sometimes independent evidence may tend to make an admission reliable without tending to establish other elements of the offense, and sometimes it may tend to establish other elements without fortifying the truth of the admission. 
of expenditures in excess of reported income tends to establish one element of the crime, but in this case does not logically fortify the truth of the admission); evidence which tends to fortify the truth of the admission, but which need not touch any element of the corpus delicti (evidence of large expenditures during the prosecution period also fails logically to fortify the truth of the defendant's admission that he had no prior accumulated funds). Evidence insufficient to establish the whole of the corpus delicti cannot be used to corroborate an admission of one element of the corpus delicti when that evidence does not fortify the truth of the admission. Of course, this objection to the adequacy of corroboration can be made only if elements of the method of proof are treated as elements of the corpus delicti.

In holding that the requirement of corroboration extends to extrajudicial admissions, the Court was probably motivated by a desire to preserve the effectiveness of the net-worth method for proving tax evasion. Corroboration is a firmly rooted and psychologically appealing requirement in the criminal law, and perhaps the Court cannot be criticized for straining to find that the corpus delicti was sufficiently established by independent evidence of an equivocal sort. It might be wished that the Court had seen fit to wipe the slate clean by abolishing the requirement of corroboration, for it seems there would be few cases in which the prosecution could not meet the requirement of corroboration by the standards the Court accepts. Instead it will remain a superfluous technicality which will furnish grounds for allegations of error. What the Court gives with one hand, it seems to take away with the other.

\section{SOLVING AN INDUSTRIAL RELATIONS DISPUTE}

\section{THE ATTITUDE OF THE NLRB AND REVIEWING COURTS}

On March 26, 1952, Eleanor Steib, a member of the Communication Workers of America, CIO, sent a letter of resignation to her union and notified her employer, the New Jersey Bell Telephone Company, to cancel her union dues deduction authorization. These actions were taken by Miss Steib while a collective bargaining agreement containing a "maintenance of membership" clause was in effect. ${ }^{1}$ The agreement was to expire on April 5, 1952. Although Miss Steib did not pay her dues for any part of April, the union did not insist upon her discharge until October 7, 1952, explaining that the delay was ne-

\footnotetext{
${ }^{1}$ A maintenance of membership clause requires that employees who are members of a union at the beginning of a collective bargaining agreement or those who join during the life of the agreement must remain members until the expiration of the agreement. The provision affords less union security than a union shop clause by which an employee must join the union sometime after his employment. The usual maintenance of membership clause provides an escape period at the end or beginning of an agreement during which an employee may withdraw his membership without forfeiting his job.
} 